\title{
Self-Constitution and Irony
}

\section{Citation}

Korsgaard, Christine M. 2011. "Self-Constitution and Irony." In A Case for Irony, ed. Jonathan Lear, 75-83. Cambridge, MA: Harvard University Press.

\section{Published Version}

http://www.hup.harvard.edu/catalog.php?isbn=9780674416888

\section{Permanent link}

http://nrs.harvard.edu/urn-3:HUL.InstRepos:33946920

\section{Terms of Use}

This article was downloaded from Harvard University's DASH repository, and is made available under the terms and conditions applicable to Open Access Policy Articles, as set forth at http:// nrs.harvard.edu/urn-3:HUL.InstRepos:dash.current.terms-of-use\#OAP

\section{Share Your Story}

The Harvard community has made this article openly available.

Please share how this access benefits you. Submit a story.

Accessibility 


\section{Self-Constitution and Irony \\ Christine M. Korsgaard \\ Harvard University}

I haven't thought much about the topic of irony before, and when I was asked to comment on these lectures, my first thought was that Kantians probably are not very good at it. Kantians, as we all know, are nothing if not earnest. But if irony is what Jonathan Lear says that it is, then it is more than compatible with Kantianism. If it is what Lear says, then irony is just a special manifestation of the general human capacity that I have called reflective distance: the ability to get your own attitudes - in the practical case, your desires and other motives - into reflective view, to call them into question, and ask whether you should allow yourself to be moved by them or not.

As Lear has told you, I have argued that when we reflect on our own practical attitudes, and decide whether to act on them or not, we assess them in terms of what I call our "practical identities": the various roles and relationships in terms of which we value ourselves, and find our lives to be worth living and our actions to be worth undertaking. ${ }^{1}$ Motives that spring from our practical identities offer themselves as possible reasons; motives that are incompatible with them alert us to our obligations. In ratifying and rejecting our potential motives, which we do whenever we act, we give shape to our own identities and

${ }^{1}$ Christine M. Korsgaard, The Sources of Normativity (Cambridge: Cambridge University Press, 1996), §3.3.1, pp. 100-2. 
become the authors of ourselves. In the course of doing so, a part of our aim is to give ourselves the unity that is necessary for agency. ${ }^{2}$ Unity is required for agency because in order to see our movements as actions, we have to see those movements as arising from ourselves as a whole, rather than from something merely working in us or on us. To act is, as it were, to put yourself fully behind your own movements, and you can only do that to the extent you are unified. And finally, drawing on both Kant and Plato, I have also argued that in order for you to achieve this unity, your actions must be in accord with morality. Integrity in the moral sense, and, for persons, integrity in the metaphysical sense, are one and the same thing. ${ }^{3}$

But having a practical identity, valuing yourself under a certain description, is obviously itself a kind of attitude, and therefore it, like anything else, can come up for reflective review. Sometimes, the occasion for review is an incompatibility between two roles that we value, as when a woman comes to wonder whether the demands of being a dedicated professional are compatible with those of being a good mother. ${ }^{4}$ What's special about moments of irony, in

2 Christine M. Korsgaard, Self-Constitution: Agency, Identity, and Integrity (Oxford: Oxford University Press, 2009), §1.4, pp. 18-26

3 This is the general argument of Self-Constitution, but see especially §§4.4-4.5, pp. 72-80, and Chapter 9, pp. 177-206.

${ }^{4}$ One response to this that I have mentioned, but not discussed much, is to redesign the role: find a new way of carrying it out that is compatible with other demands, or with other features of the situation more generally. See Self-Constitution, §1.4.4, p. 21. I mention this here because I think 
Lear's account, is that a form of practical identity in a sense comes up for review as measured against itself: that is, as measured against the standards that are inherent in that very form of identification. An agent finds himself wondering how being a Christian can be compatible with the standards of being a Christian, or how being a teacher can be compatible with the standards of being a teacher. Seen that way, Learian irony is very nearly a form of what Kant would call critique. And just as the point of critique, as Kant famously tells us, is to curb the pretensions of knowledge in order to make room for faith, so the point of Socratic irony, according to Lear, is "to inject a certain form of not-knowing into polis-life"(1.36). A certain kind of modesty, about the reach of human knowledge and know-how, is the aim of both.

In the moment of irony, we find that we have no real idea how to perform well in some role that gives our life such meaning as it has. Nowhere is this experience more poignant or more possible than when the identity in question is that of philosopher, and the form of the ironic moment is the realization that you have no idea whether the questions you have been trying to answer are anything

this might be a particularly apt response to ironic experience in Lear's sense, and it is one way to understand Lear's account of what Ms. A, whom I will be discussing later, does. In Alfred Hitchcock's movie Stage Fright, Commodore Gill (wonderfully played by Alasdair Sim), the father of the heroine Eve, is scolded by a police detective for helping his daughter to involve herself in a dangerous situation in order to save the man she thinks she loves. "What kind of a father are you?" demands the detective. "Unique" replies Gill. That of course is Alcibiades' word for Socrates: unique. 
like the right questions, or exactly what finding answers to them is supposed to do for you even if you can. Indeed, such moments are especially troubling to philosophers. Whatever is or isn't really going on in the sciences - whether their pretensions to tell us what the universe is really like are true or not - they at least give us technology. But philosophy, like a movie star, has nothing to offer to the world but herself. Yet no philosopher who doesn't experience such moments is worthy of the name.

That isn't so with psychoanalysis, which, whatever the fate of its theoretical pretensions, at least sometimes appears to help people get well, or be happier, or something like that. But in his second lecture, Lear claims something more for it, which is that it can uncover what Lear calls "sources of unity" in the self - a discovery without which even the best of us might be a "miserable failure as a human being" (2.34). And Lear takes this to be a challenge to my own view, that the unity of agency must be produced by autonomous acts of self-conscious rational self-constitution.

To illustrate: A unifying fantasy is found to underlie various otherwise seemingly disconnected or poorly understood impulses in the life of Lear's exemplar, Ms. A. Ms. A consciously identifies as feminine, but her motives and 
impulses reveal a pattern that suggests that she has not only has, but values herself under, an identity as boyish. Bringing Ms. A's boyish identity to consciousness, according to Lear, "essentially involves facilitating the development of a capacity for irony" (2.12). The work of the analyst is to produce an ironic moment, one in which Ms. A's practical identity is called into question in its own terms. She is brought to wonder, about her own behavior and motives, "What does any of this have to do with being a woman?" (2.24)

Why is this supposed to be a problem for a view like mine? One might reply - and ultimately I will reply - that no special problem is posed by the fact that sometimes a kind of practical identity is at work in us of which we are not conscious, or even that we deliberately repress. The initial materials with which we work in constructing our particular identities come to us in all sorts of random ways. The genetic lottery assigns you a family, as well as the basic abilities and capacities that determine which activities you will be drawn to. The accidents of geographical and cultural proximity determine who your friends and associates are, and they in turn determine which groups you regard yourself as a member of, which causes you ally yourself with, and so forth. Our identities are our own to make, but the material from which we make them floats in from all over. Practical identity, as I understand it, is at once the material from which we work, and the output of our self-constituting activity. So why shouldn't it be the case that some of our practical identities, in their role as the materials with which 
we work, are the result of psychic forces working on us in ways of which we are unaware, and over which we consequently have no control? So what? Once the psychoanalyst brings the resulting forms of identity to consciousness, it is for us to decide whether we really value ourselves under those descriptions or not, just as it is in any other case. The case shows how self-knowledge can be an aid to conscious self-constitution, but, as I will argue, it does not show that conscious self-constitution can be replaced by anything else.

Lear thinks such cases pose a problem because of something either that we disagree about or that he misunderstands about my view - I am not sure which. Lear thinks that the fact that we discover unity in Ms. A's various impulses challenges an assumption that is clearest in Plato's moral psychology: namely that the "lower" part of the soul is "disparate, heterogeneous, multifarious, lacking in unity"(2.4). The appetitive part of the soul in Plato's famous metaphor is a many-headed beast. ${ }^{5}$ In contrast, Lear characterizes Ms. A's unconscious identity as a "deeply rooted source of psychic unity." (2.35) And he says therefore we should call into question "the picture of rationality as simply consisting in my ability to step back and reflect on how well items of consciousness conform to my conscious practical identity." (2.36; my emphasis)

\footnotetext{
${ }^{5}$ Republic 588c-d. In Plato: Complete Works, ed. John Cooper (Indianapolis: Hackett Publishing Co., 1997), pp. 1196.
} 
But this isn't my picture of rationality. That description suggests that you simply have a practical identity, as a kind of given, and that rationality consists solely in checking whether your actions cohere with that identity or not. ${ }^{6}$ But that is not consistent with the idea that we constitute ourselves, and differs from my conception in several ways.

First of all, on my view, there is certainly heterogeneity in the materials from which we construct ourselves. We have many forms of practical identity, and they are a jumble: much of the work of self-constitution is pulling them together into a coherent whole. I do think that there is a problem in the way that both Plato and Kant presented their ideas about the "lower" part of the soul, but it isn't heterogeneity. The problem is that views like Plato's and Kant's can make it seem wholly mysterious why we ever allow ourselves to be motivated by our non-moral desires and impulses at all. Kant tends to characterize our everyday inclinations as caused in us, without much in the way of our own participation. ${ }^{7}$

\footnotetext{
${ }^{6} \mathrm{cf}$. Also Lear's remark in lecture one, after quoting Kierkegaard, that "The suggestion here is not that if only we would reflect on what our practical identity already commits us to then we would be taking on the difficult task of becoming human" (1.4). That is not my suggestion either. As I am about to argue, we are always actively re-endorsing, and potentially re-considering, our identities, not just living up to established commitments.

7 Except in "Conjectures on the Beginning of Human History," (in Hans Reiss, ed., Kant: Political Writings, translated by H. B. Nisbet. Cambridge: Cambridge University Press, $2^{\text {nd }}$ edition, 1991) where Kant does envision the participation of reason, and therefore the agent's thinking, as contributing to the formation of uniquely human desires. See my account of this in SelfConstitution, §6.2.1, pp. 117-118.
} 
At a notorious moment in the Groundwork, he announces that we should prefer to be rid of them; at another moment he says that they are not a part of our proper self. ${ }^{8}$ Yet he thinks that absent moral reasons why not, we will act on them, and are rational to do so. If our ordinary desires are just so much random debris blowing in from the causal network, we might wonder why it's rational to act on them at all. Plato, in a similar way, seems to suggest that we should identify with reason but not with our appetites; if appetite is like a many-headed beast, he proposes, reason is like a human being. ${ }^{9}$ The idea that our desires and impulses are grounded in our practical identities is intended to address this problem. Now I have already admitted that I do think there is something right about the idea that we come to occupy the roles and relationships that give rise to our nonmoral desires in rather random and contingent ways. But still, those are the roles and relationships that give our lives meaning, and we identify with the desires arising from them for that reason.

8Immanuel Kant, Groundwork of the Metaphysics of Morals, translated by Mary Gregor (Cambridge: Cambridge University Press: 1997), p. 37 (4:428) and p. 62 (4:458), respectively. But in Religion within the Boundaries of Mere Reason (translated by George di Giovanni, Cambridge: Cambridge University Press, 1998) he takes it back. "Considered in themselves, natural inclinations are good, i.e., not reprehensible, and to want to extirpate them would not only be futile, but harmful and blameworthy as well; we must rather curb them, so that they will not wear each other out but will instead by harmonized into a whole called happiness"(p. 78 (6:58)). But this does not solve the problem I mention in the text.

${ }^{9}$ Republic 588d, p. 1196; I discuss the question whether these thinkers are committed to the view that we should identify with reason in Self-Constitution, §7.2.10, pp. 140-141; and §7.5.3, 154-8. 
But the idea of practical identity is not supposed to solve the problem of unity: unity, in my view, is the result of the unifying activity of the agent herself. That is, it is result of the activity of making decisions in a way that preserves your integrity, so that you will count as the author of the resulting actions. In my view, we do not just compare our motives to the demands of a preexisting identity. We do check to see whether our motives are consistent with our practical identities, and probably we act accordingly. But I think that every time you decide to act in a way that conforms to your practical identity, you count as re-endorsing that form of identity and making it your own, and you can always reject it. Your identity is never just a given, but something you are always at work at constructing, and - within the limits of the demand for integrity - how you construct it is really up to you.

The reason why we have to see it this way, the reason why this matters, is because of something important about the nature of human agency. Any agent, even a non-human animal, must be seen as the cause of certain effects in the world. But a human agent determines herself to be the cause of the effects she produces: that is to say, she self-consciously undertakes to make herself the cause of those effects. Lear says that an agent's action is free if it can genuinely be understood as coming from her, and insists that Ms. A's various boyish acts "would seem to be acts that are paradigmatically coming from her, though the source of the self from which they come remains obscure to her" (2.12). But Ms. 
A's boyish acts - considered as expressions of a boyish practical identity - only come from her in the same sense that a squirrel's act of burying an acorn comes from the squirrel: they are expressions of her nature. ${ }^{10}$ Human actions must "come from us" in a different, richer sense, because they come from an agency or identity that we constitute ourselves. And we constitute ourselves as the agents from whom our actions spring by endorsing the identities from which they spring. But Ms. A cannot perform any actions from an endorsement of her boyish nature until it comes into her own reflective view. So until Ms. A consciously incorporates her boyish nature into her unified identity, she cannot fully be the author of any actions to which it gives rise.

10 Perhaps this is overstated. But there is a general problem about some of the phenomena characteristically studied by psychoanalysts, Freudian slips, for example, which is relevant here. Such phenomena have the kind of intelligibility that chosen actions do - we can say what the person's "reasons" for acting as she does are; but they seem to be caused rather than chosen. In this respect, the kinds of "reasons" Ms. A has for doing boyish things are rather like the "reasons" for loving someone. Those also seem to operate causally rather than as grounds of choice, yet (in some cases) seem to make the love intelligible. I discuss the problem in "The General Point of View: Love and Moral Approval in Hume's Ethics" in Korsgaard, Christine M. The Constitution of Agency (Oxford: Oxford University Press, 2009), pp. 263-301; see especially §1.3, pp. 267-270. 
I have some other worries about whether Ms. A's case really is a case of ironic experience in the sense laid out in Lear's first lecture. Lear's claim that it is rests on an analogy between Ms. A's envisioned response and the responses of the Christian and the teacher whom we met in lecture one. Lear characterizes Ms. A's therapeutic experience this way:

“... there is a disruption of ordinary conscious life which, put into words, has this shape: "What does any of this have to do with being a woman?" (2.24)

This is supposed to be like the way in which the teacher wondered what any of his activities have to do with teaching (1.18). But Learean irony is supposed to involve the realization that it is essential to you to live up to a certain standard, while you don't really know what counts as meeting that standard: what counts as being a Christian or a teacher? Does Ms. A realize that it is essential to her be a woman, but that she doesn't know what counts as being a woman?

That doesn't seem obvious, for consider what happens next. Lear says: “...there is no particular direction in which a person in Ms. A's position ought to go. She may consciously reaffirm the very shape of her conscious practical identity, stay with the received image of femininity she has lived with all along (only now it will be accompanied by the ironized sense of its possibilities); or she may opt for a playful mixture; she may decide she is bi-sexual, 
transsexual, cross-gendered, gay, or re-enter heterosexual life. From the first-order perspective of establishing a gender-identity, the analysis is not moving in any particular direction." (2.25)

These alternatives - being gay, bi-sexual, transsexual and so forth - aren't naturally understood as alternative ways of being a woman. Some of them might seem more naturally described as ways of realizing that it isn't important to her identity as a sexual being that she is a woman. And what Lear says suggests that it is her identity as a sexual being, or more broadly her gender identity, which is the subject of the ironic experience. But having some form of gender-identity or other - as opposed to having a particular one - is not, in itself, a form of practical identity. At one point, Lear characterizes ironic experience this way: "we seem to be called to an ideal that, on the one hand, transcends our ordinary understanding, but to which we now experience ourselves as already committed" (1.14). So perhaps his idea is that Ms. A experiences herself as called to boyishness, and responding to that in one of the specified ways. But I think it would be bizarre to think that a revision of her identity as a sexual being was an acceptable outcome of Ms. A's call to boyishness, even if it is a perfectly acceptable thing in itself. Let me explain.

I am more than willing to grant that there is no particular direction in which Ms. A ought to go - in the sense that nothing counts as simply getting it right about one's "gender identity." But surely there are things that count as 
getting it wrong. Hitherto, it seems, both Ms. A's conscious and unconscious identities have been governed by the most banal gender stereotypes - or as Lear puts it more kindly, "received images" (2.11). ${ }^{11}$ Ms. A herself, if I've understood the story rightly, considers it to be boyish to be the one who pays the bills, to be the one who is on top during sex, to be professionally successful, and to like sports. But we have been offered no evidence that Ms. A is sexually attracted to women, unless that is supposed to be somehow implied by her lack of interest in her husband. Yet we are offered the possibility that, even in the absence of such attraction, Ms. A might conclude that she is bisexual or gay - or decide to be bisexual or gay, however you want to put that. Surely a woman who spots a pattern of "boyishness" in her liking to pay the bills and be successful and so forth, and concludes that therefore she is or should be bisexual or gay, even in the absence of any attraction to members of her own sex, has simply got things wrong. Liking to pay the bills and be successful has nothing whatever to do with how you should construct your sexual identity. So if this is her response to the analysis, then she seems to have come out of the analysis even more weirdly

\footnotetext{
${ }^{11}$ Lear claims that Ms. A was not unreflective about her conscious practical identity as feminine, since she had read the feminist literature and "took her feminine dress to be an expression of her version" (2.11). He thinks that this shows that reflection was used in the service of staying with those received social images. I think it shows that not every form of babbling to oneself counts as reflection.
} 
enslaved to the banal gender stereotypes than she was before. How can that be the result of ironic insight?

Leaving that aside, I am left with a question about the relation between irony and self-constitution. As I mentioned earlier, Lear claims that one may be a law-abiding member of the Kingdom of Ends, with a consciously constructed identity of one's own, and yet be "a miserable failure as a human being" (2.34). But is the failure supposed to rest in the lack of ironic insight itself, or in the failure to draw on unconscious sources of the self that supposedly can result from ironic experience? What Lear says in his second lecture suggests it is the second.

Let me try to say why that seems wrong to me. Socrates is Kierkegaard's and Lear's exemplar of irony, and he is Plato's and Korsgaard's exemplar of successful self-constitution. ${ }^{12}$ If we are right to cast Socrates in both of those roles, we can ask: what is the connection between his irony and his successful self-constitution? In his first lecture, Lear rewrote a famous story told by Alcibiades, in which Socrates stands still out of doors all night, while his bemused companions move their bedding outside, in order to watch and see

12 This isn’t explicit, but see Self-Constitution, xiii, and also §9.1.5, p. 180. 
how long he will carry it on. Alcibiades says that Socrates stands still because "he's thinking about a problem" and "he won't give it up." Lear disagrees. He says: "Socrates is standing still not because he is too busy thinking, but because he cannot walk, not knowing what his next step should be" (1.34).

I think Alcibiades is right here and Lear is wrong. To me, the arresting thing about Socrates is his utter self-possession. He is always so completely himself, in any sort of circumstance: in battle, while being tried by the Athenians for his life, on the day of his death. Self-constitution is a process that takes place from the inside, but most of us are hampered in our efforts to shape our own identities by forces from outside. Anyone else would have become embarrassed and moved off if those around him made a spectacle of him in the way that Socrates's companions did on that night. And Ms. A's lack of self-possession her enslavement to banal sexual stereotypes - probably reflects the effect of social pressure in a similar if deeper way. But neither the elementary pressures of social embarrassment nor the threat of death can deter Socrates from doing what he decides to do, or being who he has decided to be. How is his irony related to his integrity? Although it's paradoxical, it seems plausible to me to say that Socrates's awareness of the possibility that none of us quite knows what we are doing is part of what enables him to proceed with such confidence. He's not measuring himself against an artificial standard, or an imagined superior knowhow on the part of others. He knows that every human action is a kind of leap of 
faith, but he also knows that the condition is so utterly universal that it can't be a reason for hesitation or half-heartedness. ${ }^{13}$ But if something like that is right, it's Socrates's ironic insight itself that contributes to his integrity, not his ability to draw on unconscious sources of the self. So while I am sympathetic to the view that irony and integrity may be related, I do not see the relation as one that challenges the self-constitution view.

13 Although it isn't exactly the same, see my account of some closely related worries about the efficacy of human action and how they give rise to the need for faith in Self-Constitution, §5.2, pp. 84-90. 